\title{
The association between fecal enterotoxigenic $B$. fragilis with colorectal cancer
}

\author{
Fakhri Haghi, Elshan Goli, Bahman Mirzaei and Habib Zeighami* (D)
}

\begin{abstract}
Background: Enterotoxigenic Bacteroides fragilis (ETBF) is an enterotoxin-producing bacterium that possibily has a role in the occurrence and progression of colorectal cancer (CRC) by modulating the mucosal immune response and inducing epithelial cell changes. The aim of this study was to investigate the frequency of ETBF in stool samples of CRC patients and healthy volunteers.

Methods: A total of 60 stool samples from confirmed CRC patients and 60 stool samples from healthy volunteers with no personal or familial history or diagnosis of colorectal disease were collected. Stool samples were screened for direct detection of $B$. fragilis using PCR targeting the marker genes of neu and bft. Enterotoxin isotypes bft- $1, b f t-$ 2 and bft-3 were also detected in B. fragilis positive samples.

Results: The frequency of $B$. fragilis among CRC and control cases was 58.3 and $26.6 \%$, respectively $(P<0.05)$. The rate of bft gene in $C R C$ cases was significantly higher than in controls $(P<0.05)$. Also, the presence of bft gene in CRC patients stage III was significantly higher than stages I and II $(P<0.05)$. Enterotoxin isotype bft-2 was detected with higher frequency among $C R C$ patients than healthy control $(P<0.05)$.

Conclusion: Our results show the association between fecal ETBF and CRC, and we suggest that detection of ETBF may be a potential marker for colorectal cancer diagnosis. However, additional investigations on tumor and paired normal tissue samples are required to substantiate this possible correlation.
\end{abstract}

Keywords: Bacteroides fragilis, Enterotoxin, bft gene, Colorectal cancer, Stool

\section{Background}

Colorectal cancer (CRC) is one of the most common types of cancers, with the fourth highest mortality rate among all cancers worldwide [1,2]. Diet (high red meat/ low fiber), obesity, smoking, alcohol consumption and inheritance are the most important risk factors for initiation and progression of CRC [2,3]. Recent studies showed the significant association between CRC development and intestinal microbiota [4].The dietary risk of CRC is probably associated with dysbiosis of the gut microbiota and their metabolites [1]. It is supposed that bacterial species such as enterotoxigenic Bacteroides fragilis (ETBF), Fusobacterium nucleatum, Clostridium septicum, Enterococcus faecalis, Helicobacter pylori, Streptococcus bovis and Escherichia coli

\footnotetext{
* Correspondence: zeighami@zums.ac.ir

Department of Microbiology, School of Medicine, Zanjan University of

Medical Sciences, Zanjan, Iran
}

have a role in colorectal carcinogenesis $[4,5]$. It has been shown that secreted bacterial toxins increase the cancer risk via toxin-mediated DNA damage. Furthermore, the release of reactive oxygen species (ROS) and the expression of cytokines and chemokines after bacterial infections can be exacerbate ROS-mediated DNA damage [6, 7].

B. fragilis is the most frequent anaerobe isolated from clinical cases of diarrhea, peritonitis, intra-abdominal abscesses and sepsis $[1,3,8,9]$. Previous studies showed the significant correlation between the presence of ETBF in stool or colonic biopsy specimens and active inflammatory bowel disease and CRC [3, 8-10]. Zinc-dependent metalloprotease toxin called the $B$. fragilis toxin (BFT) cleaves the extracellular domain of cell surface protein E-cadherin and resulting in the complete degradation of the E-cadherin. The cytoplasmic domain of E-cadherin associates with the nuclear signaling protein $\beta$-catenin. The loss of E-cadherin

(C) The Author(s). 2019 Open Access This article is distributed under the terms of the Creative Commons Attribution 4.0 International License (http://creativecommons.org/licenses/by/4.0/), which permits unrestricted use, distribution, and reproduction in any medium, provided you give appropriate credit to the original author(s) and the source, provide a link to the Creative Commons license, and indicate if changes were made. The Creative Commons Public Domain Dedication waiver (http://creativecommons.org/publicdomain/zero/1.0/) applies to the data made available in this article, unless otherwise stated. 
triggers $ß$-catenin nuclear signaling, induces $c$-myc expression and IL- 8 secretion $[2,8,9,11]$. BFT also causes oxidative DNA damage, epithelial barrier damage and activation of STAT3/Th17 immune responses [3, 7]. So, it is possible that long-term colonization of colonic epithelial cells with ETBF may increase the risk of CRC [6]. In apc -deficient mice, BFT induced interleukin 17 (IL-17)-dependent inflammation and distal CRC progression [12, 13]. Previous studies have demonstrated that ETBF level in tumor and stool samples were significantly higher in late stages (III/IV) of CRC compared to control tissues [11, 14]. In study conducted by Toprak et al., the bft gene was detected in stool samples of $38 \%$ of CRC patients, while it was present in $12 \%$ of the samples in control group [8].

The aim of this study was to investigate the frequency of ETBF in stool samples of CRC patients and healthy volunteers to find the possible correlation between fecal ETBF with CRC.

\section{Methods \\ Sample collection}

Between March 2016 and February 2018, a total of 60 stool samples were collected from confirmed CRC patients admitted to oncology ward of Valiasr hospital in Zanjan province, Iran. Also, 60 stool samples were collected from healthy volunteers with no personal or familial history or diagnosis of colorectal disease as control group. None of the cases or controls had a previous history of diarrhea and antibiotic therapy within the past 1 month. This study was approved by the Research Ethics Committee of Zanjan University of Medical Sciences (ZUMS.REC.1394.235) and informed consent was obtained from all participants at the time of samples collection.

\section{DNA extraction}

Extraction of DNA from stool samples was performed according to the protocol provided with the GeneAll Exgene $^{\mathrm{rm}}$ Stool DNA Mini Kit (GeneAll Biotechnology, Korea). The concentration and purity of DNA samples were determined using a NanoDrop Spectrophotometer (ND-1000, Nano-Drop Technologies, Wilmington, DE) at 260 and $260 / 280 \mathrm{~nm}$, respectively.

\section{Detection of $B$. fragilis in stool samples by PCR}

Stool samples were screened for direct detection of $B$. fragilis using PCR as described previously [15-17]. The marker genes of neu and bft (encoding neuraminidase and $B$. fragilis toxin, respectively) were used as speciesspecific targets. PCR was performed using DreamTaq PCR Master Mix (Ampliqon, Denmark), which contains Taq polymerase, dNTPs, $\mathrm{MgCl} 2$ and the appropriate buffer. Each PCR tube contained $25 \mu$ reaction mixture composed of $12.5 \mu \mathrm{l}$ of the master mix, $1.5 \mu \mathrm{l}$ of each forward and reverse primer solution (in a final concentration of $200 \mathrm{nM}$ ) (Metabion, Germany), $1 \mu \mathrm{l}$ of DNA with concentration of $200 \mathrm{ng} / \mu \mathrm{l}$ and nuclease-free water to complete the final volume. PCR was performed using the Gene Atlas 322 system (ASTEC, Japan). Amplification involved an initial denaturation at $94{ }^{\circ} \mathrm{C}, 5 \mathrm{~min}$ followed by 35 cycles of denaturation $\left(94^{\circ} \mathrm{C}, 1 \mathrm{~min}\right)$, annealing $\left(62^{\circ} \mathrm{C}\right.$ for neu and $52{ }^{\circ} \mathrm{C}$ for $\left.\mathrm{bft}, 1 \mathrm{~min}\right)$ and extension $\left(72^{\circ} \mathrm{C}, 1 \mathrm{~min}\right)$, with a final extension step $\left(72{ }^{\circ} \mathrm{C}, 7 \mathrm{~min}\right)$. The amplified DNA was separated by submarine gel electrophoresis, stained with ethidium bromide and visualized under UV transillumination (UVITEC, UK). The ETBF strain D-134 was used as the positive control strain.

\section{Detection of enterotoxin isotype encoding genes of $B$. fragilis}

The enterotoxin isotype encoding genes (bft-1, bft-2 and $b f t-3)$ were detected in B. fragilis positive samples as described previousely [17]. Triplex PCR was performed according to following program: initial denaturation at $94{ }^{\circ} \mathrm{C}, 5 \mathrm{~min}$ followed by 35 cycles of denaturation $\left(94{ }^{\circ} \mathrm{C}\right.$, $1 \mathrm{~min})$, annealing $\left(62^{\circ} \mathrm{C}, 1 \mathrm{~min}\right)$ and extension $\left(72^{\circ} \mathrm{C}\right.$, $1 \mathrm{~min})$, with a final extension step $\left(72^{\circ} \mathrm{C}, 5 \mathrm{~min}\right)$.

\section{Statistical analysis}

The data were analyzed with SPSS version 17.0 software (SPSS, Inc., Chicago, IL). Pearson's chi-square or Fisher's exact test were used to determine the statistical significance of the data. A $P$ value of $<0.05$ was considered significant. Relative risk calculation with $95 \%$ CI was performed only for $2 \times 2$ tables.

\section{Results}

In our study, a total of 60 stool samples of CRC cases (with a male: female ratio of 30:30) and 60 from healthy control cases (male: female ratio of 30:30) were investigated. The median age of CRC cases was 53 years (range 29-90 years) and for healthy controls was 51 years (range 33-85). The majority of CRC cases were stage II or III cancer (26 (43.3\%) in stage II; and $23(38.3 \%)$ in stage III). Also, 11 (18.3\%) CRC cases were stage I. None of the cases or controls had a previous history of diarrhea and antibiotic therapy within the past 1 month.

Direct detection of $B$. fragilis from stool samples was performed based on determination of neuraminidase (neu) and B. fragilis toxin (bft) encoding genes. As shown in Table 1, the frequency of neu gene among CRC and control cases was 58.3 and $26.6 \%$, respectively. So, the frequency of $B$. fragilis among CRC patients was significantly higher than control group $(P<0.05)$. Furthermore, the bft gene was detected among 19 (31.6\%) of CRC cases, compared with 5 (8.3\%) of healthy controls. The rate of $b f t$ gene in CRC cases was significantly 
Table 1 Frequency of neu and bft genes in CRC cases and control group

\begin{tabular}{lllll}
\hline Target gene & $\begin{array}{l}\text { CRC cases } \\
(n=60)\end{array}$ & $\begin{array}{l}\text { Healthy control cases } \\
(n=60)\end{array}$ & $P$ value & $\begin{array}{l}\text { Total number } \\
(n=120)\end{array}$ \\
\hline neu & $35(58.3 \%)$ & $16(26.6 \%)$ & 0.001 & $51(42.5 \%)$ \\
bft & $19(31.6 \%)$ & $5(8.3 \%)$ & 0.002 & $24(40 \%)$ \\
\hline
\end{tabular}

higher than in controls $(P<0.05)$. The presence of $b f t$ gene in stool samples of CRC patients with respect to disease status is shown in Table 2. The presence of $b f t$ gene in CRC patients stage III was significantly higher than stages I and II $(P<0.05)$. The frequency of $b f t$ isotypes (bft-1,bft-2 and $b f t-3)$ is shown in Table 3 . The frequency of $b f t-2$ isotype in CRC cases was significantly higher than healthy control group $(P<0.05)$.

\section{Discussion}

Various studies suggest that gut microbial dysbiosis may be related to some disorders such as inflammatory bowel disease (IBD), gastrointestinal cancers, diabetes, obesity, hypertension, renal disorders and etc. $[6,18]$. Association between gut microbiota and CRC has been reported in several studies $[5-8,19]$. According to previous reports, bacterial species including Streptococcus species, H. pylori, E. faecalis, B. fragilis, C. septicum and $E$. coli have a role in the occurrence and progression of CRC [2]. B. fragilis is the most frequent anaerobe isolated in clinical cases of diarrhea, peritonitis, intra-abdominal abscesses and sepsis [11]. It is also associated with intestinal tumors due to enterotoxin production [2]. It has been proposed that enterotoxigenic $B$. fragilis may act as "keystone" pathogen that facilitate the establishment of dysbiotic microbial communities and induce CRC $[6,20,21]$. In the present study, the frequency of enterotoxigenic B. fragilis in stool samples of CRC patients was compared with healthy controls. According to neu gene determination, B. fragilis was detected more frequently from stool samples of CRC patients than from the matched controls (58.3 and $26.6 \%$, respectively; $P<0.05$ ). In previous study from Iran, higher numbers of $F$. nucleatum, E. feacalis, $S$. bovis, ETBF and Porphyromonas spp. were detected in adenomatous polyp cases, consisting tubular adenoma and especially villous/ tubuvillous polyp, in contrast

Table 2 Presence of bft gene in CRC patients with respect to disease status

\begin{tabular}{lllll}
\hline Stage of cancer & Stage I & Stage II & Stage III & $P$ value \\
\hline bft gene & $(n=11)$ & $(n=26)$ & $(n=23)$ & \\
bft positive $(n=19)$ & $2(18.2 \%)$ & $5(19.2 \%)$ & $12(52.2 \%)$ & 0.027 \\
bft negative $(n=41)$ & $9(81.8 \%)$ & $21(80.8 \%)$ & $11(47.8 \%)$ & \\
\hline
\end{tabular}

Table 3 Frequency of bft isotypes in in CRC cases and control group

\begin{tabular}{lllll}
\hline bft isotypes & $\begin{array}{l}\text { CRC cases } \\
(n=60)\end{array}$ & $\begin{array}{l}\text { Health control cases } \\
(n=60)\end{array}$ & $P$ value & $\begin{array}{l}\text { Total number } \\
(n=120)\end{array}$ \\
\hline bft- 1 & $7(11.6 \%)$ & $3(5 \%)$ & 0.322 & $10(8.3 \%)$ \\
bft- 2 & $10(16.6 \%)$ & $1(1.6 \%)$ & 0.008 & $11(9.2 \%)$ \\
bft- 3 & $2(3.3 \%)$ & $1(1.6 \%)$ & 1.000 & $3(2.5 \%)$ \\
\hline
\end{tabular}

to samples from the normal groups $(P<0.001)$ [19]. It is reported that over time accumulation of ETBF strains in colonic epithelial crypts may enhance carcinogenesis [14].

In our study, the rate of $b f t$ gene in CRC cases was significantly higher than in controls $(P<0.05)$. This result supports prior works where $b f t$ detection in stool and colon mucosal samples were significantly higher in CRC patients than in outpatient controls [8, 14]. According to Boleij et al. study, the mucosa of CRC patients was significantly more often $b f t$-positive on left (85.7\%) and right (91.7\%) tumor compared with left and right control biopsies $(53.1 \% ; P=.033$ and 55.5\%; $P=.04$, respectively) [14]. It is assumed that BFT exposure in the human colon may induces rapid onset of chronic IL-17-dependent inflammation, oxidative DNA damage, epithelial barrier damage and activation of STAT3/ Th17 immune responses yielding to increased risk of CRC $[3,6,10,19]$.

The presence of $b f t$ gene in CRC patients stage III was significantly higher than stages I and II $(P<0.05)$. According to Boleij et al. and Viljoen et al. studies, $b f t$ was detected in the majority of CRC patients in particular with late-stage disease, possibly due to enhanced anaerobiosis on larger tumors $[11,14]$.

Furthermore, the frequency of $b f t-2$ isotype in CRC cases was significantly higher than healthy control group $(P<0.05)$. Similar to our study, Boleij et al. show bft-2 as the most common mucosal isotype of $B$. fragilis [14]. According to in vitro and in vivo surveys, BFT-2 has greater potency and biological activity compared to BFT-1 and exhibites enhanced carcinogenic potential [14]. However, in study conducted by Ulger Toprak et al., $b f t-1$ was detected more than $b f t-2$ in stool samples of colon cancer patients and control group. The bft-1 isotype was also found in all isolates of extraintestinal sites in their study [22]. Also, bft-1 isotype was the most frequent allele among ETBF strains isolated from diarrheal diseases [14, 22].

One of the limitations of the present study was the small size of CRC group. Furthermore, data regarding environmental factors and some clinicopathological and demographic characteristics that may contribute to carcinogenesis were not collected from CRC patients in our study. 


\section{Conclusions}

Our study revealed that bft gene in stool samples of CRC patients stage III was significantly higher than in controls. Also, the frequency of $b f t-2$ isotype in CRC cases was significantly higher than controls. Our results show the association between fecal ETBF and CRC, and we suggest that detection of ETBF or $b f t-2$ isotype may be a potential marker of colorectal cancer. However, additional investigations on tumor and paired normal tissue samples in CRC patients are recommended to substantiate this possible correlation.

\section{Abbreviations \\ BFT: Bacteroides fragilis Toxin; CRC: Colorectal Cancer; ETBF: Enterotoxigenic Bacteroides fragilis; neu: Neuraminidase; PCR: Polymerase Chain Reaction}

\section{Acknowledgements}

The authors would like to acknowledge all staff of Ayatollah Mousavi and Valiasr hospitals for their support in sampling.

\section{Authors' contributions}

Project development, Manuscript writing, Data analysis: H.Z; Data collection, Project development: E.G; Project development, Data management, Data analysis, Manuscript writing: F.H; Data analysis, Manuscript writing: B.M. All authors read and approved the final manuscript.

\section{Funding}

This work as an MSc thesis in Medical Microbiology was supported by the Zanjan University of Medical Sciences (A-12-392-15). The study was designed, condu cted, analyzed, and written by the authors without involvement of any commercial party.

\section{Availability of data and materials}

The datasets will not be available on a publically available website, but it may be possible to provide access to anonymized data. Anyone who wants to request the data can contact with Habib Zeighami, corresponding author.

\section{Ethics approval and consent to participate}

Ethical clearance was obtained from the Ethics Committee of Zanjan University of Medical Sceinces before conducting the study. The study was based on clinical samples were collected from Zanjan University hospitals as Ethic no. ZUMS.REC.1394.235. All participants provided written informed consent to participate in the studies.

\section{Consent for publication}

Not applicable.

\section{Competing interests}

The authors declare that they have no competing interests.

Received: 31 May 2019 Accepted: 30 August 2019

Published online: 05 September 2019

\section{References}

1. Park CH, Eun CS, Han DS. Intestinal microbiota, chronic inflammation, and colorectal cancer. Intest Res. 2018;16(3):338-45.

2. Liu C-J, Zhang Y-L, Shang Y, Wu B, Yang E, Luo Y-Y, Li X-R. Intestinal bacteria detected in cancer and adjacent tissue from patients with colorectal cancer. Oncol Lett. 2019;17(1):1115-27.

3. Yu LC, Wei SC, Ni YH. Impact of microbiota in colorectal carcinogenesis: lessons from experimental models. Intest Res. 2018;16(3):346-57.

4. Jahani-Sherafat S, Alebouyeh M, Moghim S, Ahmadi Amoli H, GhasemianSafaei $\mathrm{H}$. Role of gut microbiota in the pathogenesis of colorectal cancer; a review article. Gastroenterol Hepatol Bed Bench. 2018;11(2):101-9.

5. Hale VL, Jeraldo P, Chen J, Mundy M, Yao J, Priya S, Keeney G, Lyke K, Ridlon J, White BA, et al. Distinct microbes, metabolites, and ecologies define the microbiome in deficient and proficient mismatch repair colorectal cancers. Genome medicine. 2018;10(1):78.
6. Purcell RV, Pearson J, Aitchison A, Dixon L, Frizelle FA, Keenan Jl. Colonization with enterotoxigenic Bacteroides fragilis is associated with early-stage colorectal neoplasia. PLoS One. 2017;12(2):e0171602.

7. Bundgaard-Nielsen C, Baandrup UT, Nielsen LP, Sorensen S. The presence of bacteria varies between colorectal adenocarcinomas, precursor lesions and non-malignant tissue. BMC Cancer. 2019;19(1):399.

8. Toprak NU, Yagci A, Gulluoglu BM, Akin ML, Demirkalem P, Celenk T, Soyletir $\mathrm{G}$. A possible role of Bacteroides fragilis enterotoxin in the aetiology of colorectal cancer. Clin Microbiol Infect. 2006;12(8):782-6.

9. Wu S, Morin PJ, Maouyo D, Sears CL. Bacteroides fragilis enterotoxin induces c-Myc expression and cellular proliferation. Gastroenterology. 2003;124(2): 392-400.

10. Dahmus JD, Kotler DL, Kastenberg DM, Kistler CA. The gut microbiome and colorectal cancer: a review of bacterial pathogenesis. J Gastrointest Oncol. 2018:9(4):769-77.

11. Viljoen KS, Dakshinamurthy A, Goldberg P, Blackburn JM. Quantitative profiling of colorectal cancer-associated bacteria reveals associations between fusobacterium spp., enterotoxigenic Bacteroides fragilis (ETBF) and clinicopathological features of colorectal cancer. PLoS One. 2015;10(3): e0119462.

12. Wu S, Rhee KJ, Albesiano E, Rabizadeh S, Wu X, Yen HR, Huso DL, Brancati FL, Wick E, McAllister $F$, et al. A human colonic commensal promotes colon tumorigenesis via activation of $\mathrm{T}$ helper type $17 \mathrm{~T}$ cell responses. Nat Med. 2009;15(9):1016-22.

13. O'Keefe SJ. Diet, microorganisms and their metabolites, and colon cancer. Nat Rev Gastroenterol Hepatol. 2016:13(12):691-706.

14. Boleij A, Hechenbleikner EM, Goodwin AC, Badani R, Stein EM, Lazarev MG, Ellis $B$, Carroll KC, Albesiano E, Wick EC, et al. The Bacteroides fragilis toxin gene is prevalent in the colon mucosa of colorectal cancer patients. Clin Infect Dis. 2015;60(2):208-15.

15. Jotwani R, Kato N, Kato H, Watanabe K, Ueno K. Detection of Bacteroides fragilis in clinical specimens by polymerase chain reaction amplification of the neuraminidase gene. Curr Microbiol. 1995;31(4):215-9.

16. Pantosti A, Malpeli M, Wilks M, Menozzi MG, Ambrosio F. Detection of enterotoxigenic Bacteroides fragilis by PCR. J Clin Microbiol. 1997; 35(10):2482

17. Kato N, Kato H, Watanabe K, Ueno K. Association of Enterotoxigenic Bacteroides fragilis with bacteremia. Clin Infect Dis. 1996;23(Supplement_1): S83-6.

18. Sekirov I, Russell SL, Antunes LC, Finlay BB. Gut microbiota in health and disease. Physiol Rev. 2010;90(3):859-904.

19. Rezasoltani S, Asadzadeh Aghdaei H, Dabiri H, Akhavan Sepahi A, Modarressi MH, Nazemalhosseini Mojarad E. The association between fecal microbiota and different types of colorectal polyp as precursors of colorectal cancer. Microb Pathog. 2018;124:244-9.

20. Gao Z, Guo B, Gao R, Zhu Q, Qin H. Microbiota disbiosis is associated with colorectal cancer. Front Microbiol. 2015;6:20

21. Moore WE, Moore LH. Intestinal floras of populations that have a high risk of colon cancer. Appl Environ Microbiol. 1995;61(9):3202-7.

22. Ulger Toprak N, Rajendram D, Yagci A, Gharbia S, Shah HN, Gulluoglu BM, Akin LM, Demirkalem P, Celenk T, Soyletir G. The distribution of the bft alleles among enterotoxigenic Bacteroides fragilis strains from stool specimens and extraintestinal sites. Anaerobe. 2006;12(2):71-4.

\section{Publisher's Note}

Springer Nature remains neutral with regard to jurisdictional claims in published maps and institutional affiliations.

\section{Ready to submit your research? Choose BMC and benefit from:}

- fast, convenient online submission

- thorough peer review by experienced researchers in your field

- rapid publication on acceptance

- support for research data, including large and complex data types

- gold Open Access which fosters wider collaboration and increased citations

- maximum visibility for your research: over $100 \mathrm{M}$ website views per year

At $\mathrm{BMC}$, research is always in progress.

Learn more biomedcentral.com/submission 